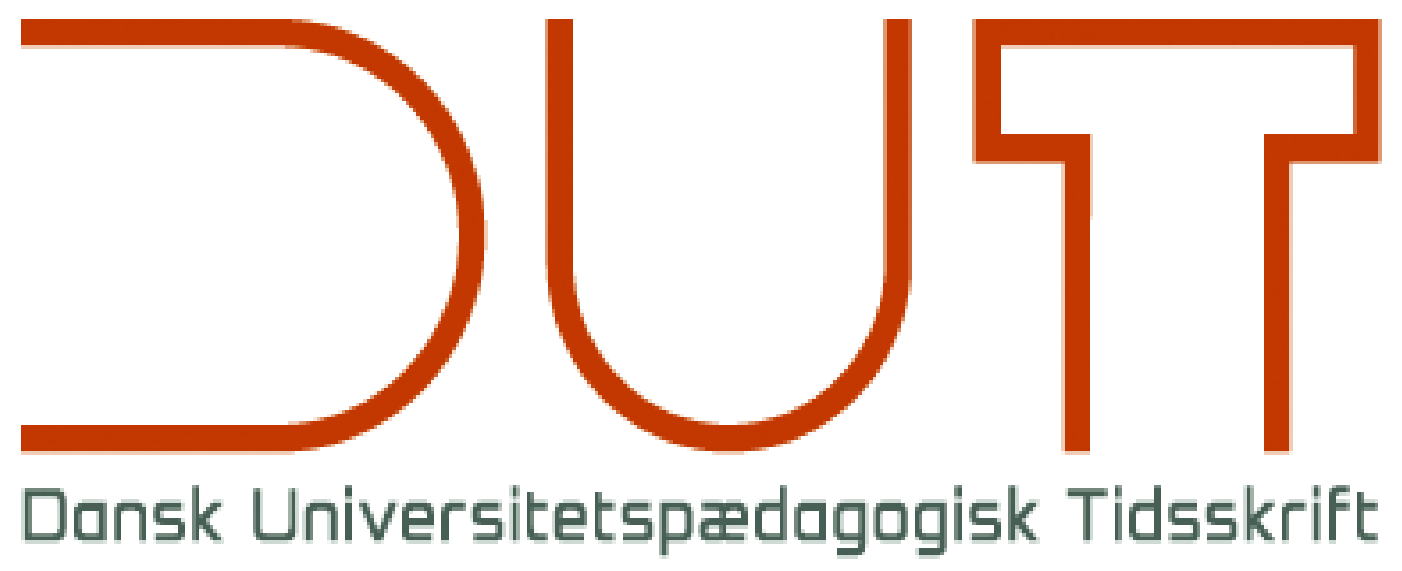

Tema

Ledelse, udvikling og overlevelse på universitetet

Årgang 12 nr. 22 / 2017

Titel

Ph.d.-vejlederkurser i Danmark: Status på indhold og diskussion af kvalitet

Forfatter

Sidetal

Sofie Kobayashi, Mirjam Godskesen og Gitte Wichmann-Hansen

$99-114$

Udgivet af

Dansk Universitetspædagogisk Netværk, DUN

URL

> http://dun-net.dk/

Betingelser for brug af denne artikel

(c) Copyright
Denne artikel er omfattet af ophavsretsloven, og der må citeres fra den. Følgende betingelser skal dog være opfyldt:

- Citatet skal være i overensstemmelse med „god skik“

- Der må kun citeres „i det omfang, som betinges af formålet"

- Ophavsmanden til teksten skal krediteres, og kilden skal angives ift. ovenstående bibliografiske oplysninger.

DUT og artiklens forfatter 


\section{Ph.d.-vejlederkurser i Danmark: Status på indhold og diskussion af kvalitet}

Sofie Kobayashi, adjunkt ved Institut for Naturfagenes Didaktik ved Det Natur-og Biovidenskabelige Fakultet, Københavns Universitet

Mirjam Godskesen, selvstændig konsulent og ekstern lektor ved Institut for Læring og Filosofi, Aalborg Universitet

Gitte Wichmann-Hansen, lektor ved Center for Undervisning og Læring på School of Business and Social Sciences, Aarhus Universitet

\section{Reviewet artikel}

I denne artikel kortlægger vi kompetenceudviklingsaktiviteter for ph.d.-vejledere i Danmark, hvilket ikke tidligere er gennemført systematisk. Syv ud af de otte danske universiteter udbød kompetence-udviklingsaktiviteter for ph.d.vejledere. I alt identificerede vi 14 kurser/aktiviteter gennemført i 2015. Undersøgelsen er dels baseret på data fra en tematisk analyse af eksisterende kursusbeskrivelser og programmer, dels på en spørgeskemaundersøgelse. Kortlægningen viser, at fire faglige temaer går igen i de fleste kurser: vejlederroller, relationer, understøttelse af den ph.d.-studerendes selvstændighed samt kommunikation. Kortlægningen diskuteres op imod international litteratur fra forskningsfeltet med særlig fokus på et australsk studie, hvor udbuddet af ph.d.-vejlederkurser kortlægges på otte store (forskningstunge) australske universiteter. Udbuddet i Danmark er forholdsvis ensartet sammenlignet med både Australien og aktiviteter rapporteret fra andre lande, hvor en større variation af formater er afprøvet, fx onlinekurser og uformelle læringscirkler. Herefter tages spørgsmålet om kvalitet i kompetenceudviklingsaktiviteterne op. Internationalt vurderes kvalitet i ph.d.-vejlederkurser på, hvorvidt det lykkes at få vejlederen til at reflektere over sin praksis. Vi har derfor valgt at diskutere kvalitet med udgangspunkt i Schöns begreber om 'refleksion-over-praksis' og 'refleksion-i-praksis' (Schön, 1987). Målet er, at artiklen kan bruges af ph.d.-skoler og pædagogiske enheder til videreudvikling af deres udbud af kurser og andre initiativer målrettet ph.d.-vejledere.

\section{Introduktion}

I takt med en markant stigning i optaget af ph.d.-studerende både i Danmark og globalt er der kommet større opmærksomhed på forskning og udvikling inden for ph.d.vejledning (John \& Denicolo, 2013). Forskningen tog fart i 1990'erne og kan knyttes sammen med et voksende fokus på universitetspædagogik generelt (Wichmann-Hansen, Eika \& Mørcke, 2007). Fokus er generelt skiftet fra, at undervisning og vejledning 
er den enkelte undervisers ansvar til også at være et organisatorisk fokusområde for universiteterne (Hénard \& Roseveare, 2012; Kvalitetsudvalget, 2015; McAleese et al., 2013). Dermed er den konkrete pædagogiske opkvalificering af ph.d.-vejledere, som dette studie belyser, også blevet en opgave for universiteterne.

International forskning viser en stor variation i omfanget af kompetenceudviklingstilbud for ph.d.-vejledere - fra universiteter, der kun tilbyder en kort indføring i vejlederens rolle og ansvar til andre, der har semesterlange kurser (Wisker \& Kiley, 2012). De mest brugte tilgange er kurser, workshops og seminarer (Kiley, 2011), men der er også eksempler på andre tilgange, som fx e-læringskurser, narrative og refleksive tilgange under mere uformelle former og mentorordninger. Forskellige narrative tilgange er beskrevet af Lindén (1999), McCormack (2009) og Manathunga, Peseta, og McCormack (2010). En anden tilgang er at skabe rum for erfaringsudveksling og refleksion, for eksempel læringscirkler (learning circles), som beskrevet af Manathunga (2005), frokostmøder udformet som refleksive samtaler blandt ph.d.-vejledere (Spiller, Byrnes, \& Bruce Ferguson, 2013) eller gruppecoaching af ph.d.-vejledere kombineret med oplæg om kommunikation og psykologi (Emilsson \& Johnsson, 2007).

Som vist ovenfor er litteraturen forholdsvis rig på studier af forskellige kursus- og undervisningsmetoder inden for kompetenceudvikling af ph.d.-vejledere. Imidlertid er der meget begrænset litteratur om, hvilke emner og indholdsområder, der adresseres på ph.d.-vejledningskurser. Formålet med denne artikel er at præsentere et samlet overblik over igangværende kompetenceudviklingsforløb for ph.d.-vejledere i Danmark med særligt fokus på indholdet i kurserne. Vi vil også diskutere, hvad der kendetegner kvalitet i disse forløb ved at sammenholde vores fund med studier, der specifikt opstiller kvalitetsparametre for vejledningskurser. Det er vores mål, at artiklen skal kunne danne grundlag for en diskussion af kursuselementer i fremtidens kompetenceudvikling for ph.d.-vejledere i Danmark og kunne bruges af ph.d.-skoler og pædagogiske enheder til videreudvikling af deres kursusudbud og andre initiativer for ph.d.-vejledere. Af flere årsager fokuserer vi bevidst diskussionen på kursusindhold og ikke kursusmetoder. For det første giver undersøgelsen og diskussionen af kursusindhold et større bidrag til forskningslitteraturen - som før nævnt. For det andet vil en diskussion af undervisningsmetoder indebære en større og helt anden diskussion om, hvad 'god undervisning' og 'god uddannelsesudvikling' generelt er. Og det ligger uden for undersøgelsens rækkevidde. Vi er bevidste om, at evalueringer, undervisernes pædagogiske kompetencer og incitamentsstrukturer alle er væsentlige komponenter i en analyse af kursernes kvalitet, men det bliver for omfattende at inkludere her.

Først præsenteres et kort overblik over de danske kursers form og omfang, hvorefter vi fokuserer på indholdet i kurserne. Nærværende studie er det første af sin art i Danmark. I Australien har Kiley (2011) kortlagt og analyseret udbuddet af kurser og aktiviteter ved de otte store, forskningstunge universiteter (Group of Eight). I sammenligningen af fund fra vores studie med andre studier har vi valgt at fokusere på studier 
fra Australien, da det er her, størstedelen af litteraturen på området stammer fra, og da det ikke er ærindet at lave et internationalt review på området.

Endelig giver vi et bud på kriterier for at diskutere kvalitet af kompetenceudviklingsaktiviteterne. Her trækker vi på to australske studier, McCulloch og Loeser (2016) samt McCormack og Pamphilon (2004), som bl.a. bygger på Schön (1987), og vi udbygger deres kvalitetsmål om 'refleksion-over-egen-praksis' med 'refleksion-i-egen-praksis'.

\section{Metode}

Målet med dataindsamlingen var at afdække alle kompetenceudviklingsaktiviteter for ph.d.-vejledere i Danmark og tegne et retvisende billede af de aktiviteter, der jævnligt og tilbagevendende udbydes på danske universiteter. Dataindsamling og analyse blev foretaget i februar-marts 2016, og materialet inkluderede alle aktiviteter, som var udbudt og gennemført i perioden januar-december 2015. Kriteriet om jævnligt og tilbagevendende aktiviteter blev defineret som kurser og forløb, der var gennemført som en del af et fast institutionsforankret kompetenceudviklingsudbud på det pågældende universitet eller fakultet, og som med stor sandsynlighed ville blive videreført i 2016. Det sidste blev baseret på, at kurset var annonceret og materialiseret på nettet i form af kursusbeskrivelse, tilmeldingslink, mm. Det betød, at vi ekskluderede enkeltstående arrangementer, fx et foredrag eller en eftermiddagsworkshop med en inviteret oplægsholder fra udlandet.

Datamaterialet bestod dels af besvarelser på et online spørgeskema og dels af analyse af eksisterende kursusbeskrivelser. Alle kursusledere for ph.d.-vejlederkurser i DK $(\mathrm{N}=12)$ blev identificeret gennem NUP (det nationale netværk for udvikling af ph.d.vejledere under DUN (dun-net.dk/sigs-special-interest-groups/), og spørgeskemaet blev distribueret i februar 2016. Svarprocent var $92 \%(N=11)$, og efter opfølgning havde vi svar fra alle. Skemaet bestod af ni spørgsmål om faktuelle forhold, fx kursusfrekvens, længde og deltagerantal. Vi rekvirerede samtidig kursusbeskrivelser og programmer for alle kurser, og gennem opfølgning lykkedes det at indsamle et komplet sæt kursusbeskrivelser og programmer for alle kurser.

Datamaterialet rummer mulighed for at analysere en række forskellige aspekter af kursusudbuddet for ph.d.-vejledere i Danmark, som fx længde, struktur og organisatorisk indlejring, men fokus i denne artikel er indholdet i kurserne. Det er analyseret gennem en tematisk analyse af kursusprogrammerne (Braun \& Clarke, 2006), hvor hvert enkelt undervisningsmodul (typisk en-fire timer) blev navngivet, og et mindmap blev lavet over alle moduler på alle kurser. Det skete i et samarbejde, hvor to forskere skulle nå til enighed, før moduler blev navngivet og elementer placeret. Gennem to yderligere iterationer identificeredes 14 undervisningsemner fordelt på tre overordnede kategorier samt fem praktiske opgaver/øvelser, der blev brugt i forbindelse med kurserne. 
Præliminære resultater blev valideret på et netværksmøde i NUP i marts 2016, hvor 11 kursusledere var til stede og fik mulighed for at vurdere, om indholdet i deres kurser var dækket af den oversigt, vi havde lavet. Kun to mindre kommentarer førte til rettelser i materialet.

\section{Resultater}

For at sætte rammen giver vi først et kort overblik over vejlederkursernes form og omfang, hvorefter resultatet af den tematiske analyse af kursernes indhold præsenteres. På syv ud af de otte danske universiteter har der jævnligt været udbudt kompetenceudviklingsaktiviteter for ph.d.-vejledere. For hovedparten gælder, at kurserne er relativt nye, idet de er blevet etableret som fast praksis over de seneste par år, med undtagelse af et par få universiteter (KU og AU, der har udbudt vejlederkurser regelmæssigt siden 2008) samt DTU (siden 2010). I alt identificerede vi 14 aktiviteter, der kan karakteriseres som jævnligt tilbagevendende tilbud i Danmark. Med undtagelse af et årligt kursus, der udbydes af DUN på tværs af universiteter og fakulteter, er alle de identificerede kursusaktiviteter disciplinspecifikke, idet de generelt udbydes fakultetsvist. Enkelte steder udbydes aktiviteterne dog i fællesskab mellem to fakulteter på det samme universitet, hvor der er interessesammenfald mellem disciplinerne, $f x$ sundhedsvidenskab og naturvidenskab. Af de i alt 14 aktiviteter er de 13 struktureret som kurser varierende fra en til fire kursusdage og med en varighed på mellem seks og 60 timer. Kurserne udbydes en-to gange årligt og med et deltagerantal, der varierer fra seks til 40. Indsatsen fra deltagernes side strækker sig fra blot tilstedeværelse til omfattende hjemmeopgaver inkluderende videooptagelser og kollegasupervision. Af de 14 aktiviteter var der én aktivitet, der ikke kunne karakteriseres som et egentligt kursus. Det er et forløb over 6 måneder baseret på såkaldt 'kollegial intervision', som i princippet er det samme som kollegasupervision. Forløbet består af et indledende og et afsluttende seminar, og i den mellemliggende periode arbejder deltagerne $\mathrm{i}$ grupper af tre, hvor de observerer hinandens praksis og efterfølgende giver feedback i gruppen efter særlige regler for interaktionen. Det er de 13 kurser, der indgår i den tematiske analyse.

Gennem den tematiske analyse nåede vi frem til tre overordnede kategorier af undervisningstemaer: 1) vejledningsmodeller, værdier og forståelse, 2) konkrete praksisser og 3) konteksten for vejledningen. I det følgende beskrives kategorierne, og i tabellerne under hver kategori fremgår det, hvilke konkrete emner, de dækker over. I tabellen vises også, hvilke konkrete indholdselementer, der er inkluderet i hvert emne. 


\section{Vejledningsmodeller, værdier og forståelse}

Kategorien vejledningsmodeller, værdier og forståelse handler om vejlederens forståelse af sin egen vejledning og refleksion over egen praksis. Der sættes fokus på relationen mellem ph.d.-studerende og vejleder, og der undervises i teoretiske vejledningsmodeller og metoder til rolle- og relationsafklaring. Forskellen mellem procesperspektiv og produktperspektiv på ph.d.-uddannelse tages op, og der arbejdes med både projektledelse og understøttelse af den ph.d.-studerendes udvikling til selvstændig forsker. I tabel 1 ses de emner, der behandles.

\begin{tabular}{|l|l|}
\hline Emner & Indholdselementer \\
\hline Roller & Vejledningsstil \\
& 'Refleksion-over-praksis' \\
& Vejleders formål og motivation \\
& Pædagogisk tilgang \\
\hline Relationer & Forventningsafstemning \\
& Ansvar \\
& Asymmetri \\
& Ph.d.-studerendes erfaringer og perspektiv \\
\hline Understøtte selvstændighed & Hands-on/hands-off \\
& Situationsbestemt ledelse \\
& Vejledning som undervisningsform \\
& Opbygge tro på egne evner \\
\hline Projektledelse & Overblik over faser og processer \\
& Projektplanlægning og opfølgning \\
& Planlægge udlandsophold \\
\hline
\end{tabular}

Tabel 1. Emner under kategorien vejledningsmodeller, værdier og forståelse.

\section{Konkrete praksisser}

Kategorien Konkrete praksisser handler om, hvordan man gør som vejleder Her er kommunikation og redskaber til at drive en dialog helt centrale emner. Indholdselementerne er derfor spørgeteknik, aktiv lytning og metakommunikation. Andre vigtige emner er feedback, herunder at støtte den studerendes skriveproces samt at hjælpe vejlederen med at skærpe sin opmærksomhed på den ph.d.-studerendes trivsel og reagere ved tegn på stress og kriser. 


\begin{tabular}{|l|l|}
\hline Emner & Indholdselementer \\
\hline Kommunikation & Spørgeteknik \\
& Metakommunikation \\
& Aktiv lytning \\
\hline Trivsel og krisehåndtering & $\begin{array}{l}\text { Trivsel } \\
\text { Stress } \\
\end{array}$ \\
& 'Early warning signs' \\
& 'The vicious circle' \\
& Kriser \\
\hline Feedback & Konstruktiv feedback \\
\hline Skrivning & Skriveprocesser \\
& Sprog \\
\hline
\end{tabular}

Tabel 2. Emner under kategorien konkrete praksisser.

\section{Konteksten for vejledningen}

En vigtig opgave for vejledere er at navigere i universitetet som kontekst for vejledningen. Det indebærer at kende til regelsæt og procedurer, fx angående halvårsevalueringer og finansiering, men også at rekruttere ph.d.-studerende, at kunne navigere i forskningsmiljøer både nationalt og internationalt samt at støtte den ph.d.-studerende til selv at navigere i og være bevidst om sin karriereudvikling.

\begin{tabular}{|l|l|}
\hline Emner & Indholdselementer \\
\hline På tværs af kulturer & $\begin{array}{l}\text { Interkulturel kommunikation } \\
\text { Viden om andre vejledningskulturer }\end{array}$ \\
\hline Regelsæt & $\begin{array}{l}\text { Regler og procedurer for ph.d.-uddannelse } \\
\text { God videnskabelig praksis } \\
\text { Grænser for ansvar }\end{array}$ \\
\hline Forskningsmiljø & $\begin{array}{l}\text { Netværk nationalt og internationalt } \\
\text { Videndeling } \\
\text { Rekruttering og karriere }\end{array}$ \\
& $\begin{array}{l}\text { Rekruttering } \\
\text { Talentudvikling } \\
\text { Karrierevejledning }\end{array}$ \\
\hline
\end{tabular}

Tabel 3. Emner under kategorien kontekst for vejledningen.

\section{Hvor hyppigt forekommer de enkelte emner i kurserne?}

I tabel 4 gives et overblik over, hvor udbredt de enkelte emner er i undervisningen på kurserne. Som det fremgår af tabellen, indgik følgende fire emner i hovedparten af kurserne, dvs. i flere end ni ud af de 13 kurser: roller, relationer, understøttelse af selvstændighed og kommunikation. Mindre centrale emner, dvs. emner, som kun blev 
taget op på mellem fem og otte af kurserne, var: trivsel og krisehåndtering, feedback, tværkulturel vejledning, regelsæt, skrivning og forskningsmiljø. Endelig var der kun få kurser (mellem to og fire), der adresserede emnerne projektledelse samt rekruttering og karriere.

\begin{tabular}{|l|l|l|l|}
\hline & $\begin{array}{l}\text { De fleste kurser } \\
(\mathrm{N}=9-13)\end{array}$ & $\begin{array}{l}\text { En del kurser } \\
(\mathrm{N}=5-8)\end{array}$ & $\begin{array}{l}\text { Enkelte kurser } \\
(\mathrm{N}=\mathbf{2}-4)\end{array}$ \\
\hline Emner & $\begin{array}{l}\text { Roller } \\
\text { Relationer } \\
\text { At understøtte selv- } \\
\text { stændighed } \\
\text { Kommunikation }\end{array}$ & $\begin{array}{l}\text { Trivsel og krisehåndte- } \\
\text { ring } \\
\text { Feedback } \\
\text { Tværkulturel vejled- } \\
\text { ning } \\
\text { Regelsæt } \\
\text { Skrivning } \\
\text { Forskningsmiljø }\end{array}$ & $\begin{array}{l}\text { Rekruttering og karri- } \\
\text { ere }\end{array}$ \\
\hline
\end{tabular}

Tabel 4. Hvor udbredt er de enkelte emner i de 13 kurser?

\section{Hjemmeopgaver og træning}

Størstedelen af kurserne omfatter også forberedelse i form af hjemmeopgaver og øvelser før, mellem og efter kursusgangene. Skrivning af egne narrativer eller cases bruges på halvdelen af kurserne og fungerer typisk som forberedelse til kurserne. De tjener samtidig til, at underviserne får en ide om, hvad deltagerne har udfordringer med og interesse for. Disse narrativer kan variere fra få linjer til flere siders beskrivelse og refleksion.

Kollegasupervision er også udbredt og bruges på fem af kurserne. Det indebærer typisk observation af andre kursusdeltageres vejledning samt feedback på deres praksis før og efter selve vejledningsmødet med den studerende. Der er stor forskel på, hvor omfattende og stringent en proces, der lægges op til på de forskellige kurser.

På et enkelt kursus indgår træning af aktiv lytning i egen vejledningspraksis, og på to kurser indgår forventningsafstemning som træning i egen praksis.

Skrivning af vejlederbreve indgår på fire kurser og er en anledning til at formulere, hvem man er som vejleder, hvad man forventer af sine ph.d.-studerende, og hvad de kan forvente af vejlederen. Selve skrivningen af vejlederbrevet tjener til at reflektere over og eksplicitere den måde, man vejleder på, ligesom brevet også kan udleveres til nye ph.d.-studerende som forberedelse på og invitation til en fælles mundtlig forventningsafstemning (Laustsen, Wichmann-Hansen, Aagaard, Bahrami, \& Dreyer, 2012). 
Endelig er der to kurser, der inkluderer professionel coaching af vejlederne, og to kurser, der anvender videooptagelse af deltagernes vejledning. Begge teknikker fremhæves ofte i litteraturen som metoder, der har stor effekt i forhold til at få vejledere og undervisere til at reflektere over og ændre egen praksis, idet den individuelt tilpassede sparring er direkte brugbar for vejlederne (Saroyan \& Trigwell, 2015).

\section{Diskussion}

\section{Sammenligning af kursusindhold i Danmark og Australien}

I det følgende diskuterer vi, hvordan udbuddet i Danmark matcher udbuddet i lande, vi ofte sammenligner os med. Vi har lavet en kortlægning af det danske udbud af kompetenceudvikling og søgt efter tilsvarende nationale og/eller internationale kortlægninger, men det eneste studie, vi har kunnet finde, som gør noget sammenligneligt, er Kileys kortlægning af kurser ved de otte store australske universiteter (Kiley, 2011). Hun har kortlagt indholdet i kurserne og deler indholdselementerne op i 'centrale' og 'ikke centrale' emner, dvs. Emner, der hyppigt eller mindre hyppigt adresseres. I tabel 5 sammenstiller vi Kileys resultater med resultaterne fra vores kortlægning. Når man sammenligner to undersøgelser, der ikke er lavet med samme metode, vil der være temaer, som enten lapper over eller er defineret forskelligt, men vi kan alligevel se klare tendenser, forskelle og ligheder i materialet. I tabellen tages der udgangspunkt i Kileys kategorisering af emner. Enkelte steder har vi sat de danske emner i parentes, så det bliver mere tydeligt, hvilke emner vi sammenligner med hinanden.

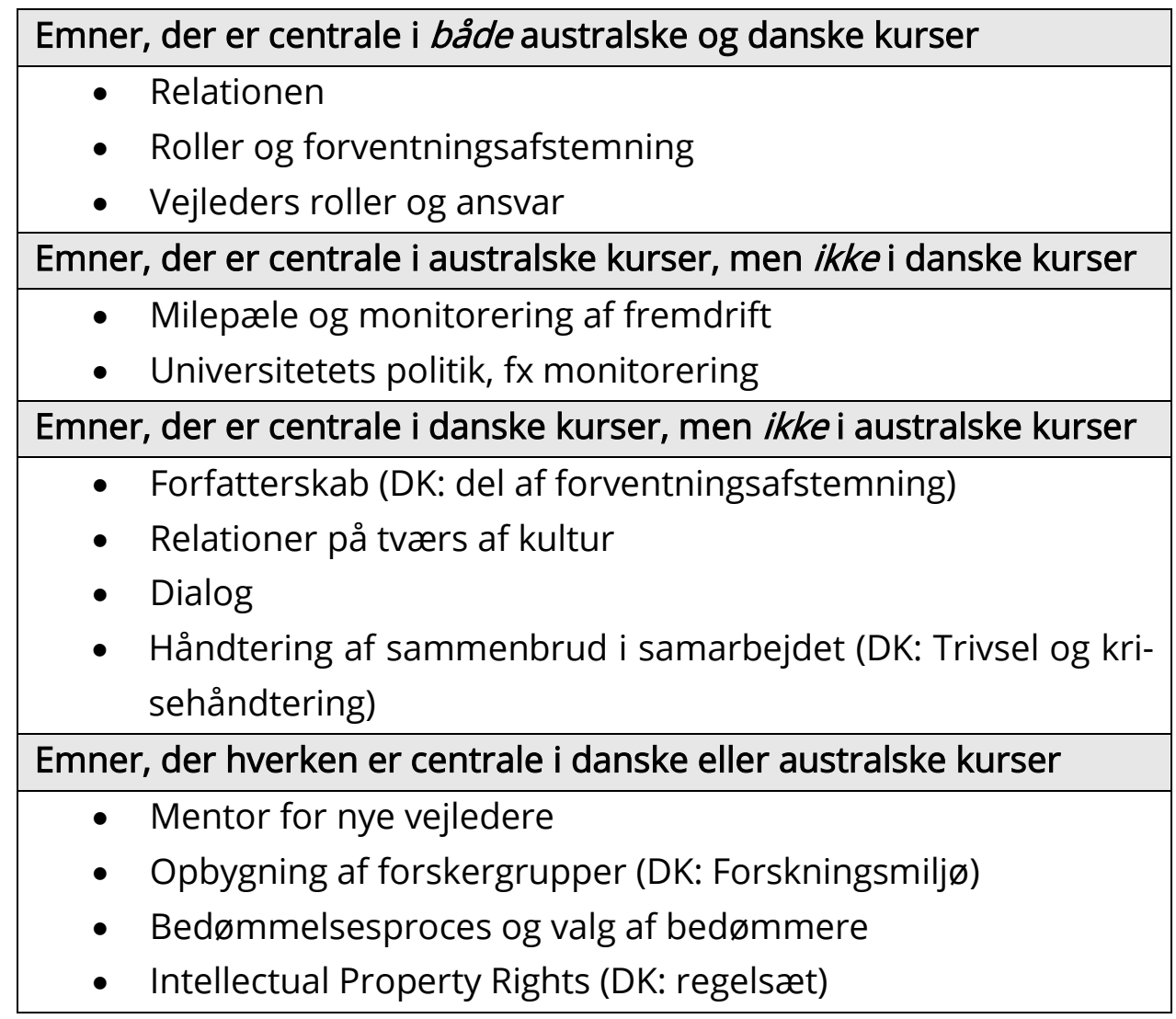

Tabel 5. Sammenstilling af emner fra vores studie og Kileys studie (2011). 
De emner, der er centrale i begge undersøgelser, er vejledningsrelationen, forventningsafstemning og vejlederrollen. Det stemmer godt overens med de anbefalinger, man finder i vejledningslitteraturen af, hvilke overvejelser og refleksioner, det er vigtigt at gøre sig som vejleder. I en række reviews (Boud \& Brew, 2013; Engebretson et al., 2008; Pearson \& Brew, 2002) når forfatterne frem til, at bevidsthed om forskellige vejledingsmodeller og -roller er afgørende for, at vejledere systematisk kan reflektere over egen praksis. Det er særlig vigtigt, at vejlederne får redskaber til at etablere og vedligeholde gode samarbejdsrelationer med studerende og medvejledere, herunder at kunne kommunikere hensigtsmæssigt og afstemme forventninger undervejs i forløbet. Pearson og Brew (2002) fremhæver specifikt vigtigheden af, at vejledere udvider deres repertoire af strategier, så de kan indrette deres vejledning efter situationens behov og dermed øge deres fleksibilitet til gavn for både sig selv, projektet og de studerende.

For os at se er det et positivt træk ved det danske udbud, at netop disse emner, hvor der lægges op til analyse af egen praksis, vejledningsroller og samarbejdet med den studerende, udgør kernen i kurserne. Det vidner om, at udviklingen af kompetenceudviklingen i Danmark i den henseende er på rette spor (Pearson \& Kayrooz, 2004).

En væsentlig forskel, der træder frem i denne sammenstilling, er, at emner, der drejer sig om monitorering af den ph.d.-studerendes fremskridt samt institutionens politik på området, er udbredt i Australien, men mindre udbredt i de danske kursusudbud (indgår kun i seks af de danske kurser). En forklaring på dette kan være, at de australske universiteter i højere grad og på et tidligere tidspunkt har været underlagt en managementkultur, der skal sikre høj gennemførselsprocent og rettidighed (McCallin \& Nayar, 2011). Spørgsmålet er imidlertid, om der i stigende grad er behov for også at adressere emnet på de danske kurser i lyset af de ændrede politiske vilkår for ph.d.uddannelsen i Danmark i det seneste årti. Flere forfattere (Cleys-Kulik \& Estermann, 2015; Uller, 2016; Wichmann-Hansen \& Herrmann, 2016) peger på, at det øgede optag af ph.d.-studerende samt udbredelsen af den performancebaserede model til fordeling af basismidler til universiteterne i Europa kan presse vejledere til at få mange ph.d.-studerende igennem på kort tid og dermed presse vejlederne til at blive mere styrende og produktorienterede. Det er samtidig vores erfaring, som kursusledere på vejlederkurser, at ph.d.-vejledere i Danmark i stigende grad er optaget af, hvordan de håndterer dette pres, hvilket samlet set kunne tale for at gøre emnet til en fast bestanddel af de fremtidige kurser.

En anden interessant iagttagelse er, at der i de danske kurser arbejdes meget med dialogen, fx i form at aktiv lytning, metakommunikation og differentiering mellem forskellige spørgsmålstyper. Vi ser ikke denne dimension i Kileys undersøgelse, og vi fik 
bekræftet, at det er et fremmed element for kursusudviklerne i Australien, da vi præsenterede nogle af disse metoder på QPR16 ${ }^{1}$ (Wichmann-Hansen, Godskesen, \& Kiley, 2016). Diskussionen af forfatterskab er et andet element, der indgår i de danske kurser som en del af emnet om forventningsafstemning, men som kun sjældent adresseres i de australske kurser. Grunden til dette kan være, at det er mere almindeligt at skrive artikelbaserede afhandlinger i Danmark, mens det stadig er en nyere praksis i Australien (Jackson, 2013).

Endelig kan det være interessant at se på de emner, som ganske vist kun sjældent tages op i de australske kurser, men som slet ikke blev fundet i det danske udbud. Det drejer sig bl.a. om bedømmelsesprocessen, forsvarshandlingen og valg af bedømmere. Det kan være et udtryk for, at en række universiteter i Australien har en mere formaliseret proces, frem til at man bliver godkendt som ph.d.-vejleder, mens man i Danmark pr. definition kan være ph.d.-vejleder, når man er blevet lektor. Det kan også være udtryk for, at der ikke er særligt klare bedømmelseskriterier for en ph.d.-afhandling (Krumsvik, Øfstegaard, \& Jones, 2016; Rienecker \& Jørgensen, 2013), ligesom der ikke er mange eksplicitte retningslinjer for valg af bedømmere (Kiley, 2009). På den anden side er dette netop gode argumenter for at sætte emnet på dagsordenen på fremtidige kurser, så det ikke forbliver en tavs og ubevidst kompetence overladt til den enkelte vejleders fortolkning og 'smag'.

Som vist i ovenstående diskussion er der gode argumenter for at tilføje en lang række emner til de eksisterende kurser. Men problemet er, som i meget anden undervisning, at der ikke er tid til at dække det hele. Et typisk vejledningskursus i Danmark varer to dage (a syv timer), hvilket i forvejen er kort tid til at dække de mest centrale emner, som forskningslitteraturen anbefaler. Vi vil fortsat anbefale at man på kurserne prioriterer de emner, som står mest centrale og velunderbyggede i forskningslitteraturen. Men det er en overvejelse værd, hvorvidt andre formater end kursusformatet (mentorordninger, frokostmøder o. lign.) bedre kan adressere emner, som er stærkt disciplinspecifikke, og som ofte skal forhandles mere lokalt. Det gælder fx emner, som hører under kategorien kontekst. forskningsmiljø, rekruttering, regler og procedurer mfl.

\section{Kvalitet}

Som en ramme for at diskutere vejledningskurserne trækker vi på to studier, der begge er fra Australien, og som differentierer mellem forskellige former for kompetenceudvikling for ph.d.-vejledere: McCormack og Pamphilon (2004) samt McCulloch og Loeser (2016). Studiet af McCulloch og Loeser (2016) opererer med to dimensioner. Den ene dimension handler om at skelne mellem den første basale indføring i det at være ph.d.-vejleder hen mod kontinuerlig efteruddannelse. Den anden dimension

\footnotetext{
${ }^{1}$ QPR (Quality in Postgraduate Research) er en af de største konferencer om ph.d.-uddannelse og gennemføres hvert andet år i Adelaide i Australien.
} 
handler om at skelne mellem kompetenceudviklingsaktiviteter, der kun omfatter konkret information, tips og adgang til ressourcer, og aktiviteter, der også inkluderer refleksion. Vi fokuserer på den sidstnævnte dimension, da denne dimension handler om indholdet i kurserne. Her refererer McCulloch og Loeser (2016) til McCormack og Pamphilon (2004), hvor dimensionen yderligere differentieres i tre niveauer for kompetenceudvikling i forhold til at være informerende og introducerende, over udvikling af færdigheder, til at engagere deltagerne i kritisk refleksion over egen praksis. Her refereres til Schöns begreb om 'refleksion-over-praksis' (1987).

I vores tematiske indholdsanalyse af de danske kurser fremkom de overordnede kategorier: 1) kontekst, 2) modeller, værdier og forståelse og 3) praksis. Disse kategorier kan til dels genfindes i McCormack og Pamphilons model, hvor de skelner mellem 'information and resources', 'skills development' og 'scholarship of supervision pedagogy'. 'Skills development svarer fint til vores 'praksis'-kategori. Deres 'scholarship' dimension dækker vores kategori om 'modeller, værdier og forståelse', men deres er mere vidtgående, idet den også inkluderer forskningsaktivitet og publicering baseret over egen praksis. Endelig inkluderer vores kontekstkategori 'information and resources', men er noget bredere, da den også dækker kulturforståelse og forskningsmiljøet.

Der er imidlertid en dimension af kompetenceudvikling, som vi kan se i det danske udbud, som vi ikke genfinder i det australske. Det drejer sig om de elementer af træning mellem kursusgangene, som mange af de danske kurser inkluderer, for eksempel at træne aktiv lytning i sin egen vejledning og øvelser med kollegavejledning. Her bruger deltagerne de mentale modeller til at eksperimentere, afprøve nye teknikker og få feedback fra fagfæller i deres egen aktuelle praksis. De aktiviteter, mener vi, kan forstås som Schöns begreb om 'refleksion- $i$-praksis'. De læringsaktiviteter, der er lagt ind i de australske kurser, indeholder 'refleksion-over-egen praksis'. De inkluderer fx casehistorier, men der gennemføres ikke aktiviteter, der befordrer 'refleksion-i-praksis', hvor man isituationen bruger mentale modeller og værktøjer til at justere sin vejledning. mens den pågår (Schön, 1987).

I den forstand matcher de danske vejlederkurser de anbefalinger, som gives i nyere studier af, hvilke mekanismer der fremmer underviseres og vejlederes professionelle læring (Saroyan \& Trigwell, 2015). Her er det en klar anbefaling, at kompetenceudviklingsaktiviteter skal bygge på en høj grad af situeret læring og interaktion mellem peers i daglige, relevante praksisfællesskaber. 'Refleksion-i-praksis' hviler netop på et princip om, at læring er situeret, og derfor skal læringssituationen være så kompleks og autentisk som muligt, hvis det, man lærer på et kursus, skal kunne bruges i ens egen vejledning. Jo mere kompetenceudviklingsaktiviteterne inddrager deltagernes egen praksis, desto bedre er deres muligheder for at internalisere de mentale modeller og dermed sandsynligheden for, at de reelt kommer til at anvende dem i vejledningen (Dolin, 2013; Perkins \& Salomon, 1992). 


\section{Kompetenceudvikling for vejledere på alle niveauer}

Et tilbagevendende spørgsmål er, hvorvidt det kun er de nye ph.d.-vejledere, der skal udvikle deres vejlederkompetencer, eller om erfarne vejledere også har brug for at reflektere over og udvikle deres kompetencer? Når man diskuterer vejledning i forskningsmiljøerne, så er der ingen tvivl om, at både ph.d.-studerende, ledere og administratorer vil mene, at også erfarne vejledere vil kunne have gavn af at udvikle deres vejledning. Vejlederkurserne i Danmark er generelt ikke designet specielt til nye eller erfarne vejledere. De teoretiske modeller, værktøjerne og de temaer der tages op er relevante for begge grupper, og hvis vejlederne har mere erfaring, vil disse kunne bringes i spil og give refleksioner af en større dybde.

Ifølge den internationale litteratur er det en stor udfordring at engagere erfarne vejledere (Hammond, Ryland, Tennant, \& Boud, 2010); de erfarne vejledere har betydelig modstand mod obligatoriske kurser og foretrækker lokale og uformelle aktiviteter. Det peger på, at der er brug for anderledes tilgange til kompetenceudvikling end de gængse kurser for at engagere de mere erfarne vejledere. Ifølge Kileys kortlægning af kompetenceudvikling for ph.d.-vejleder i Australien (2011) manglede der aktiviteter rettet mod de mere erfarne vejledere på hovedparten af universiteterne.

I Danmark har vi kurset i DUN-regi, som er målrettet erfarne vejledere. Kurset har været udbudt siden 2013 og har tiltrukket vejledere med helt op til 20 ph.d.-forløb bag sig. Kurset er specifikt tilrettelagt ud fra en intention om at skabe avanceret erfaringsudveksling mellem meget erfarne vejledere på tværs af faggrænser. I nærværende undersøgelse inkluderede vi ikke evalueringsdata fra kurserne, ligesom vi ikke inkluderede data om mindre og ad hocprægede initiativer. Erfaringsmæssigt ved vi dog, at der er miljøer, hvor vejledere i en faggruppe eller på et institut nogle gange tager initiativ til at mødes og diskutere vejledning i et lokalt praksisfællesskab. Sidstnævnte model kunne være den slags aktiviteter, som erfarne vejledere ifølge Hammond et al. (2010) foretrækker. Det kunne være nyttigt at undersøge, hvordan de forskellige kompetenceudviklingsaktiviteter for erfarne vejledere i Danmark virker, og hvordan vejlederne oplever dem og bruger dem til udvikling af egen vejledningspraksis.

\section{Konklusion}

Kortlægningen af kompetenceudviklingsaktiviteter for ph.d.-vejledere i Danmark har vist, at stort set alle universiteter har et tilbud til deres ph.d.-vejledere, at omfanget og indholdet af tilbuddene er på niveau med kurser i Australien, som vi sammenligner os med i dette studie, og på nogle punkter lykkes med at integrere elementer, der endnu ikke er udbredt i Australien.

Hvis man forstår kvalitet i kompetenceudvikling som det at integrere ny viden og refleksion i egen praksis, så er kvaliteten af de danske kurser høj. Der er et stærkt fokus på mentale modeller og værktøjer, der handler om vejlederrollen, relationen til den ph.d.-studerende og forventningsafstemning, og der arbejdes refleksivt og dialogisk 
med disse modeller i undervisningen, hvilket svarer til anbefalingerne i international forskningslitteratur på området. Samtidig skiller de danske kurser sig positivt ud, ved at der indgår elementer af træning i egen praksis.

Årsagen til at vi er så godt med i Danmark, må vi gisne om. Et bud af mere strukturel karakter er, at uddannelse af ph.d.-vejledere var et element i den opbygning af forskerskoler, der blev støttet af forskningsstyrelsen fra 2000 og frem (Forskningsstyrelsen, 2003). Vejlederkurser blev herefter institutionaliseret ved at en række ambitiøse og visionære ph.d.-skoleledere og dekaner allerede tilbage i 2008 afsatte ressourcer til udvikling og gennemførelse af vejlederkurser ved deres institutioner i samarbejde med de pædagogiske centre, hvilket har smittet positivt af på de øvrige universiteter. Hertil kommer den kontinuerlige og åbne videndeling, som løbende er sket i NUP. Dette netværk startede i 2009 og har haft deltagere fra seks af de otte danske universiteter. Gruppen har løbende delt konkrete undervisningsideer og materialer og har deltaget i hinandens kurser på kryds og tværs.

Dette studie har ikke givet grundlag for at vurdere for eksempel betydningen af universiteternes formål med vejledningskurserne eller deltagernes evalueringer af kurserne som drivkraft for udvikling. Det kunne være interessant at undersøge sådanne faktorer og deres betydning for, hvordan vejledningskurser i Danmark har udviklet sig over tid.

Sofie Kobayashi er adjunkt i naturvidenskabsdidaktik. Hendes undervisning og forskning ligger inden for det universitetspædagogiske felt med fokus på ph.d.-uddannelse og vejledning samt kompetenceudvikling inden for vejledning og undervisning.

Mirjam Godskesen udvikler kurser, underviser og forsker inden for ph.d.vejledningsfeltet. Hun coacher ph.d.-studerende og har udviklet feltet ph.d.-coaching i Danmark. Endelig arbejder hun med skriveprocesser gennem coaching og organisering af skrive-bootcamps. Hun har en ph.d. fra DTU i teknologisociologi og har været lektor på Institut for Læring og Filosofi på AAU, indtil hun blev selvstændig i 2014.

Gitte Wichmann-Hansen er cand.mag. i pædagogik og ph.d. i uddannelsesforskning. Hun arbejder som undervisningsudvikler på Aarhus Universitet og forsker i vejledning knyttet til studerendes opgaveskrivning og forskningsforløb med særligt fokus på ph.d.-uddannelser. Gitte har arbejdet med udvikling af vejledning siden 2004, ligesom hun startede det nationale netværk for udvikling af ph.d.-vejledere tilbage i 2009. Hun afholder en lang række vejledningskurser på tværs af fakulteter og universiteter i Danmark og Norden. 


\section{Litteratur}

Boud, D., \& Brew, A. (2013). Reconceptualising academic work as professional practice: implications for academic development. International Journal for Academic Development, 18(3), 208-221.

Braun, V., \& Clarke, V. (2006). Using thematic analysis in psychology. Qualitative Research in Psychology, 3(2), 77-101.

Cleys-Kulik, A.-L., \& Estermann, T. (2015). DEFINE thematic report: Performancebased funding of universities in Europe (pp. 58). Brussel: European University Association.

Dolin, J. (2013). Undervisning og læring Gymnasiepædagogik (pp. 131-143). København: Hans Reitzel.

Emilsson, U. M., \& Johnsson, E. (2007). Supervision of supervisors: on developing supervision in postgraduate education. Higher Education Research \& Development, 26(2), 163-179.

Engebretson, K., Smith, K., McLaughlin, D., Seibold, C., Terrett, G., \& Ryan, E. (2008). The changing reality of research education in Australia and implications for supervision: a review of the literature. Teaching in Higher Education, 13(1), 115.

Forskningsstyrelsen. (2003). Fra Forskerakademiet til FUR 1986-2003 (pp. 54). København: Ministeriet for Videnskab, Teknologi og Udvikling.

Hammond, J., Ryland, K., Tennant, M., \& Boud, D. (2010). Building Research Supervision and Training across Australian Universities. University of Technology, Sydney: Australian Learning and Teaching Council.

Hénard, F., \& Roseveare, D. (2012). Fostering quality teaching in higher education: Policies and Practices. An IMHE Guide for Higher Education Institutions. Jackson, D. (2013). Completing a PhD by publication: A review of Australian policy and implications for practice. Higher Education Research \& Development, 32(3), 355-368.

John, T., \& Denicolo, P. (2013). Doctoral Education: A Review of the Literature Monitoring the Doctoral Student Experience in Selected OECD Countries (Mainly UK). Springer Science Reviews, 1(1-2), 41-49.

Kiley, M. (2009). 'You don't want a smart Alec': selecting examiners to assess doctoral dissertations. Studies in Higher Education, 34(8), 889-903.

Kiley, M. (2011). Developments in research supervisor training: causes and responses. Studies in Higher Education, 36(5), 585-599.

Krumsvik, R. J., Øfstegaard, M., \& Jones, L. Ø. (2016). Retningslinjer og vurderingskriterier for den artikkelbaserte ph. d-avhandlingen.

Kvalitetsudvalget. (2015). Nye veje og høje mål - Kvalitetsudvalgets samlede forslag til reform af de videregående uddannelser (pp. 56). København: Uddannelsesog Forskningsministeriet. 
Laustsen, S., Wichmann-Hansen, G., Aagaard, H., Bahrami, G., \& Dreyer, P. (2012). Brugen af vejlederbrev til universitetsstuderende-en diskussion af dets betydning i vejledningsprocessen. Dansk Universitetspædagogisk TIdsskrift, 入12), 46-57.

Lindén, J. (1999). The contribution of narrative to the process of supervising PhD students. Studies in Higher Education, 24(3), 351-369.

Manathunga, C. (2005). The development of research supervision:“Turning the light on a private space". International Journal for Academic Development, 191), 1730.

Manathunga, C., Peseta, T., \& McCormack, C. (2010). Supervisor development through creative approaches to writing. International Journal for Academic Development, 15(1), 33-46.

McAleese, M., Bladh, A., Berger, V., Bode, C., Muehlfeit, J., Petrin, T., \& Tsoukalis, L. (2013). Report to the European Commission on Improving the quality of teaching and learning in Europe's higher education institutions. Luxembourg: Publication Office of the European Union.

McCallin, A., \& Nayar, S. (2011). Postgraduate research supervision: a critical review of current practice. Teaching in Higher Education, 171), 63-74.

McCormack, C. (2009). Stories return personal narrative ways of knowing to the professional development of doctoral supervisors. Studies in Continuing Education, 31(2), 141-156.

McCormack, C., \& Pamphilon, B. (2004). More than a confessional: postmodern groupwork to support postgraduate supervisors' professional development. Innovations in Education and Teaching International, 41(1), 23-37.

McCulloch, A., \& Loeser, C. (2016). Does research degree supervisor training work? The impact of a professional development induction workshop on supervision practice. Higher Education Research \& Development, 1-15.

Pearson, M., \& Brew, A. (2002). Research Training and Supervision Development. Studies in Higher Education, 272), 135-150.

Pearson, M., \& Kayrooz, C. (2004). Enabling critical reflection on research supervisory practice. International Journal for Academic Development, 9(1), 99-116.

Perkins, D. N., \& Salomon, G. (1992). Transfer of learning. International encyclopedia of education, 2, 6452-6457.

Rienecker, L., \& Jørgensen, P. S. (2013). Hvordan kan kriterier for ph. d.-bedømmelser danne grundlag for ph. d.-uddannelse? Pædagogiske perspektiver af en analyse af 41 ph. d.-bedømmelser fra et humanistisk fakultet. Dansk Universitetspædagogisk Tldsskrift, 8(15), 17-35.

Saroyan, A., \& Trigwell, K. (2015). Higher education teachers' professional learning: Process and outcome. Studies in Educational Evaluation, 46, 92-101. 
Schön, D. (1987). Educating the Reflective Practitioner. Toward a New Design for Teaching and Learning in the Professions. San Francisco: Jossey-Bass Publishers.

Spiller, D., Byrnes, G., \& Bruce Ferguson, P. (2013). Enhancing postgraduate supervision through a process of conversational inquiry. Higher Education Research \& Development, 32(5), 833-845.

Uller, T. (2016). External Funding of Doctoral Education: Background and Reflection. Högre utbildning, 6(1), 65-75.

Wichmann-Hansen, G., Eika, B., \& Mørcke, A. M. (2007). Hvad findes der af litteratur om vejledning? - Litteratursøgning med fokus på publicerede, evidensbaserede studier. Dansk Universitetspædagogisk Tldsskrift, 2007(3), 11-19.

Wichmann-Hansen, G., Godskesen, M., \& Kiley, M. (2016). What are successful supervisor development programs? Nordic traditions meet Australia similarities and differences. Paper presented at the Quality in postgraduate education, Adelaide, Australia.

Wichmann-Hansen, G., \& Herrmann, K. J. (2016). Does external funding push doctoral supervisors to be more directive? A large-scale Danish study. Higher education, 1-20.

Wisker, G., \& Kiley, M. (2012). Professional learning: lessons for supervision from doctoral examining. International Journal for Academic Development, 1-14. 